\title{
Spillover Effects of Internal Control Weakness Disclosures: The Role of Audit Committees and Board Connections
}

\author{
Shijun Cheng ${ }^{\dagger}$ \\ Robert H. Smith School of Business, University of Maryland \\ Shanghai Advanced Institute of Finance, Shanghai Jiao Tong University \\ Robert Felix \\ University of Baltimore \\ Raffi Indjejikian \\ University of Michigan
}

\begin{abstract}
We find that firms are less likely to report an internal control material weakness (as mandated by the Sarbanes-Oxley Act) in a given year if one of their audit committee members is concurrently on the board of a firm that disclosed a material weakness within the prior three years. We find a similar spillover effect for financial restatement disclosures. The spillover from material weakness disclosures is evident only if a shared director has more experience with the disclosing firm or can channel more information about the disclosed material weakness. Our findings suggest that prior director experiences outside the firm influence the work of audit committees inside the firm. One rationale is that a director's prior experience with an adverse disclosure helps diffuse important insights and serves as a catalyst for improvements in a firm's internal control and financial reporting practices. An alternative explanation, which we cannot dismiss, holds that a director's prior experience helps a firm to under-report material weaknesses and financial restatements without any attendant improvements in the underlying practices.
\end{abstract}

Keywords: board interlock, audit committee, internal controls, material weakness, spillover, SOX

\section{JEL: G34, G39, M41, M49}

Contact: Shijun Cheng: R.H. Smith School of Business 4332J Van Munching Hall College Park, MD 20742. Phone: 301.405.5481. Email: shijun@rhsmith.umd.edu, Robert Felix: Merrick School of Business 11 W. Mount Royale Avenue Baltimore, MD 21201 Phone: 410.837.5803. Email:rfelix@ubalt.edu, Raffi Indjejikian: Ross School of Business 701 Tappan Street Ann Arbor, MI 48109 Phone: 734.936.1460. Email:raffii@umich.edu

This is the author manuscript accepted for publication and has undergone full peer review but has not been through the copyediting, typesetting, pagination and proofreading process, which may lead to differences between this version and the Version of Record. Please cite this article as doi: 10.1111/1911-3846.12448

This article is protected by copyright. All rights reserved. 
Accepted by Clive Lennox. We are very thankful to the editor, Professor Clive Lennox, and two anonymous reviewers for their constructive comments. We also thank Cody Hyman for her excellent assistance. Cheng is grateful for financial assistance from the University of Maryland, Felix is grateful for financial assistance from the University of Baltimore, and Indjejikian is grateful for financial assistance from the University of Michigan.

$\dagger$ Corresponding author. 


\section{Introduction}

Internal controls exist to safeguard the financial reporting process; their importance is highlighted by section 404 of the Sarbanes-Oxley Act (SOX) which requires firms to annually disclose an auditor-certified assessment of internal controls. While prior studies have focused mostly on the economic consequences for firms disclosing material weaknesses (e.g., Beneish et al. 2008), we examine whether such disclosures have spillover effects on other firms. Specifically, we predict and find that firms are less likely to report an internal control material weakness (hereafter ICMW) in a given year if an audit committee member on their board concurrently serves on the board of a firm that disclosed an ICMW within the prior three years. We find a similar spillover effect for financial restatement disclosures. One explanation for our findings is that an audit committee member's prior experience with an adverse disclosure helps diffuse important insights and serves as a catalyst for improvements in a firm’s control and reporting practices. The implication is that public disclosures of negative events, such as those mandated by SOX, have positive spillovers, a benefit of SOX previously unrecognized in the literature. An alternative explanation, which we cannot dismiss, holds that a director's prior experience helps a firm to under-report control weaknesses and financial misstatements without undertaking attendant improvements.

Although shared directors are an important direct channel for inter-firm information transmission (e.g., Mizruchi 1996), we use a measure that is more germane to our setting where we require that a connecting director serves on the audit committee of the connected firm. We 
expect audit committee members with prior ICMW or financial restatement disclosure experience to have the information, incentive, and ability to substantively influence their firm's practices. For instance, audit committees that learn about ICMW disclosures of others are likely reminded of their own fiduciary responsibilities and thus are more vigilant in monitoring and improving their own internal controls. Similarly, we expect audit committees that learn about the economic consequences of ICMW disclosures or financial restatements to be motivated to improve their own practices. These are positive spillovers and reflect how public disclosures such as those mandated by SOX deter control and financial reporting deficiencies.

However, because we do not observe firms' ICMWs and misstatements directly and only observe what firms disclose, we acknowledge that audit committee members with such prior experiences can also influence their firms’ reporting practices more superficially. For instance, connecting directors, cognizant of the costs and consequences of ICMW disclosures, may ensure that their firms under-report ICMWs. Indeed, there is evidence in the literature that suggests that firms, on the whole, tend to under-report their ICMWs and restatements (DeFond and Lennox 2017; Files et al. 2009; Lennox and Li 2017; Rice and Weber 2012). Thus, for connecting directors, this motivation to under-report is potentially alluring. But unfortunately, we cannot empirically distinguish between a connecting director's motivation to under-report and the motivation to improve internal control and financial reporting practices.

Our analysis is based on a sample of firms with available director information and covers the period from November 2004, when SOX section 404 annual disclosures of internal control 
assessments became available, through December 2012. For each firm-year observation in our sample, we indicate whether an audit committee member of a firm concurrently serves on the board of another firm that disclosed an ICMW (or alternatively, a financial restatement) within the prior three years (labeled as a connected firm). We find that connected firms are less likely to disclose an ICMW than firms that are not connected. For instance, we find that a connected firm's probability of disclosing an ICMW is 2.9 percent, which is less than 3.8 percent for the typical sample firm. We find a similar spillover for financial restatements and note that a connected firm's probability of having a misstatement is 4.5 percent which is less than 5.4 percent for the typical sample firm. At the same time, we find that other connections, such as having the same auditor or operating in the same industry, have no discernable effects on a firm's probability of disclosing an ICMW or financial misstatement. ${ }^{1}$ These findings imply that connecting audit committee directors serve as an important spillover mechanism and that these types of spillovers are potentially present in other settings with similar adverse disclosures. ${ }^{2}$

To bolster our main findings that connecting directors use their prior experiences to influence their firms’ behaviors, we conduct two cross-sectional tests to identify conditions under which spillovers from ICMW disclosures are more clearly evident. First, we examine the impact of a connecting director's experience with the disclosing firm based on the intuition that connecting directors with more relevant experience can internalize ICMW-related events more fully and thus

\footnotetext{
${ }^{1}$ We also do not find any evidence that audit committee members with prior ICMW disclosure experience have a discernable effect on a firm's likelihood of disclosing a financial misstatement. This finding suggests that ICMWconnections do not affect reporting quality, at least as measured by financial misstatements.

${ }^{2}$ We thank an anonymous referee for suggesting that an important implication of our finding is that if the public disclosure of an ICMW has spillovers, then such spillovers should manifest in other settings as well.
} 
channel information to connected firms more effectively. Using three different proxies to measure a connecting director's experience, we find that the spillover is evident only if a connecting director has relevant experience at the disclosing firm.

The second cross-sectional variation we consider is the magnitude of information about the underlying ICMW that connecting directors can potentially convey. We expect the spillover to be stronger when information about the prior ICMW is more substantive and thus more beneficial to connected firms. Consistent with this intuition, we find that a connected firm is less likely to disclose an ICMW if the disclosing firm's ICMW is considered to be more pervasive.

We also provide a number of additional tests and sensitivity analyses to address measurement challenges and concerns about alternative interpretations. For instance, one concern is that connecting directors are inherently of higher quality than unconnected directors and hence our spillover findings are due to the quality of connecting directors rather than their prior experiences. A second concern is that our findings may be due to director selection whereby firms select directors with particular ICMW disclosure experience or directors select firms that are less likely to have internal control problems. While we acknowledge these concerns as potential limitations, supplementary analyses in section 5 suggest that these concerns are unlikely to explain our results.

Our main finding that the public disclosure of an ICMW disclosure (or a financial restatement) has the potential to create positive spillovers stands in contrast to recent papers that document negative spillovers from board connections (e.g., Bizjak et al. 2009; Chiu et al. 2013). 
In contrast to our setting, we note that the practices studied in prior literature are largely private and their consequences do not materialize publicly until after the disclosure. In section 5.4, we highlight this contrast and reconcile our result with prior literature.

Our findings contribute to prior literature in three ways. First, we contribute to the disclosure literature by highlighting how mandated disclosures can generate spillovers. Whereas Cai et al. (2014) find that firms imitate the voluntary disclosure policies of other firms, we find that when the disclosure is mandated, board connections inform connected firms on how to best avoid the same deficient practice. Subject to the caveat that connected firms are not merely under-reporting their deficiencies, the evidence suggests public disclosures help deter negative practices.

Second, we contribute to the literature that addresses the costs and benefits of SOX legislation. Although the costs and benefits of SOX compliance are the subject of much debate (e.g. Hochberg et al. 2009; Linck et al. 2009), the focus has been primarily on disclosing firms. Our findings suggest that the SOX-related disclosures can also have beneficial spillovers for a broader set of firms, suggesting that those disclosures likely enhance the effectiveness of the law (Scholz 1984).

Third, we add to the literature that examines the role of audit committees in the financial reporting process. By demonstrating how connected audit committee members affect firms’ internal control and reporting practices, we highlight the distinctive role audit committees play in transmitting information across firms. Specifically, our study sheds light on how the experiences of audit committee members outside the firm can impact their role inside the firm. 
The rest of the paper is organized as follows. In section 2, we provide an overview of the related literature and motivate our hypotheses. In section 3, we describe our sample and empirical methods. In section 4, we present our main results and related evidence. In section 5, we provide additional evidence and some robustness tests. In the final section, we conclude.

\section{Motivation and hypotheses}

Prior studies show that firms that publicly disclose ICMWs experience negative stock returns, higher audit fees, and higher costs of debt and equity (Ashbaugh-Skaife et al. 2009; Beneish et al. 2008; Dhaliwal et al. 2011; Hoitash et al. 2008). While the evidence is clear that ICMW disclosures have adverse consequences for disclosing firms, whether such disclosures have spillover effects on other firms is largely unexplored.

In this section, we motivate the hypothesis that ICMW disclosures generate spillovers for firms connected to disclosing firms through shared board directors. We focus on shared directors for two reasons. First, because board members are privy to information and insights within their networks beyond what is directly available to firm executives, directors provide firsthand decision-making and monitoring information to most firms (e.g., Mizruchi 1996). Second, because audit committee members are specifically charged with overseeing internal controls (DeZoort 1997), connecting directors who experience ICMW disclosures elsewhere are in a unique position to influence the work of audit committees on which they serve.

Connecting directors can influence the work of audit committees in two distinct ways. Directors with prior ICMW disclosure experience can provide constructive insights and serve as 
a catalyst for audit committees to improve their firms’ internal controls. This is a positive spillover, a real consequence of SOX-mandated ICMW disclosures and a testament to the law's effectiveness. ${ }^{3}$ However, the spillover can also be superficial. For instance, because the presence of ICMWs is not observable or easily detectable by outsiders, connecting directors can ensure that ICMWs are "under-reported” to the public even without improvements in internal controls.

There are several reasons we expect ICMW disclosures to generate a positive spillover. First, psychology literature notes that observing a peer's misdeeds will make the deed more salient and remind one of his/her own ethical standards, thus making the imitation of those misdeeds unlikely (Gino et al. 2009). Hence, we expect that audit committees that learn about ICMW disclosures of others through a connecting director are reminded of their own fiduciary responsibility to monitor and maintain sufficiently strong internal controls.

Second, social theory suggests that observing the punishment of a peer for a negative act reinforces the social norms against that act and reduces the chances of imitation (Bandura 1971). In contrast, when negative behavior is private, difficult to detect, or unpunished, the behavior appears socially acceptable and thus imitable (Bandura 1965). Accordingly, we contend that an ICMW disclosure and its attendant repercussions reinforce the notion to connected firms that weak controls are not socially (or legally) acceptable.

\footnotetext{
${ }^{3}$ Since its passage much has been written about the costs and benefits of SOX. For instance, prior studies have highlighted the costs in terms of compliance costs, reduced profitability, and increased director-related costs (Iliev 2010; Linck et al. 2009). Other papers suggest that SOX has reduced agency concerns (Hochberg et al. 2009) and strengthened investor protections (Leuz et al. 2008). However, the idea that a SOX-mandated disclosure creates positive spillovers for other "connected" firms is a unique feature of our paper.
} 
Third, economic theory suggests that all decisions, including decisions to upgrade or modify internal controls, reflect a fundamental cost-benefit tradeoff (Becker 1968). Accordingly, we expect that when the consequences and potential remedies of ICMW disclosures become apparent, connecting directors relay that information to their audit committees and shift the costbenefit tradeoff in favor of improving internal controls.

A cost-benefit tradeoff also explains why connecting directors may encourage underreporting of ICMWs, even without improvements in internal controls. Because ICMW disclosures have negative consequences for disclosing firms (e.g., higher costs of debt and equity as noted earlier), firms may not always disclose known material control weaknesses (DeFond and Lennox 2017; Rice and Weber 2012). For connecting directors, cognizant of the costs and consequences of ICMW disclosures, this motivation to under-report is potentially alluring.

The previous discussion suggests that a connecting director's motivation, either to improve internal controls or under-report ICMWs, implies that firms are less likely to disclose material control weaknesses if they are connected, through an audit committee member, to a firm that previously disclosed its own material control weakness. Thus:

HYPOTHESIS 1. Firms are less likely to disclose internal control material weaknesses if they are connected, through an audit committee member, to a firm that previously disclosed its own internal control material weakness.

Although our focus is on the spillover effects of SOX-mandated ICMW disclosures, we note that the arguments underlying $\mathrm{H} 1$ are more general; namely that public disclosures of an adverse

This article is protected by copyright. All rights reserved. 
practice by others have a spillover effect on connected firms. Thus, we expect $\mathrm{H} 1$ to prevail in other settings where adverse practices are publicly disclosed and acknowledged. In particular, we consider the disclosure of financial restatements, a setting widely investigated in the accounting literature and one that is closely linked to firms' internal control practices. As in H1, we expect firms are less likely to have a misstatement that subsequently leads to a financial restatement if they are connected, through an audit committee member, to a firm that previously reported a financial restatement. The reasons parallel those discussed earlier for H1. Unfortunately, neither improvements in internal controls nor financial reporting quality are observable; hence, the motivation to under-report restatements remains a factor in this setting as well. Connecting directors with prior financial restatement experience can provide constructive insights that help avoid similar restatements, or connecting directors can ensure that restatements are underreported. ${ }^{4}$ We have:

HYPOTHESIS 2. Firms are less likely to misstate their financial statements if they are connected, through an audit committee member, to a firm that previously restated its financial statements.

Although we present $\mathrm{H} 1$ and $\mathrm{H} 2$ as distinct hypotheses, their implications are necessarily linked. Because most internal controls exist to safeguard the financial reporting process, it follows that persistent control weaknesses reduce financial reporting quality and improvements in internal controls improve financial reporting quality. Hence, to the extent that connecting

\footnotetext{
${ }^{4}$ Lennox and Li (2017) suggest that financial restatements are under-reported by documenting that among firms that resolved a lawsuit brought against them for an accounting issue, only 24.6 percent reported a restatement.
} 
directors with prior ICMW disclosure experience improve their firms’ internal controls (rather than merely under-report ICMWs), we would expect financial reporting quality to improve as well. We test for this possibility in a supplementary hypothesis where we assume that misstatements are an indication of financial reporting quality (Chiu et al. 2013).

Unfortunately, because neither improvements in internal controls nor financial reporting quality are observable, we recognize the motivation to under-report restatements remains a factor in this setting as well. We have:

HYPOTHESIS 3 (supplementary). Firms are less likely to misstate their financial results if they are connected through an audit committee member with firms that previously disclosed their own material weakness.

\section{Research design}

\section{Sample}

Because our main objective is to examine whether ICMW disclosures by firms have spillover effects on other (connected) firms, we construct our sample around SOX-mandated disclosures concerning internal control. SOX has two provisions that require internal control disclosures: section 404 requires annual assessments that are certified by an auditor, while section 302 requires quarterly management assessments. We focus on section 404 disclosures because they are auditor-certified and because the annual disclosures are better aligned with director-level data available only on an annual basis. ${ }^{5}$

\footnotetext{
${ }^{5}$ In unreported tests, we find similar results if we classify a firm as being a material weakness-disclosing firm during a year if it reports a material weakness under section 302 in any quarter during the year.
} 
Our unit of analysis is a firm-year observation. We obtain annual data on assessments of internal control under SOX section 404 and data on financial restatements from Audit Analytics, which covers the period from November 2004, the first effective year of section 404, to December 2012. We obtain annual data on firms’ boards of directors from the Institutional Shareholder Services (ISS) database. After merging these two datasets, we start with a preliminary sample of 14,652 firm-year observations. Because firms can restate their internal control reports for a given year, we retain the most recent filing (and drop 611 firm-year observations) to ensure that we have the most accurate internal control information for each firmyear observation. We also eliminate 199 firm-year observations for firms with multiple, nonconsecutive material weakness disclosures (Gordon and Wilford 2012) to avoid confounding information from potentially unrelated ICMW disclosures. Finally, we eliminate 4,713 firm-year observations with insufficient COMPUSTAT data to calculate various control variables.

Our final sample consists of 9,129 firm-year observations, including 350 observations of ICMW disclosures and 506 reported observations with financial restatements. Because of the relatively small proportion of ICMW and restatement observations, we acknowledge that some of our analyses may lack power due to a limited number of ICMW and restatement observations.

\section{Model and variables}

We test our three hypotheses using the following logit regressions. All variables are defined in the Appendix. 


$$
\begin{aligned}
& \operatorname{Pr}\left(\text { ICMW }_{i j}=1\right)=F\left(\beta_{0}+\beta_{1} P D I_{i j}+\sum \beta_{k} \text { Other } \text { Variables }_{i j}+\varepsilon_{i j}\right)
\end{aligned}
$$

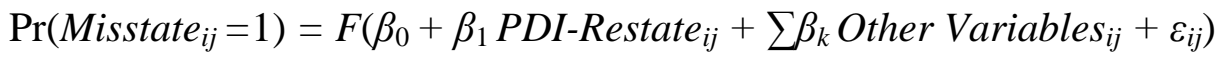

$$
\begin{aligned}
& \operatorname{Pr}\left(\text { Misstate }_{i j}=1\right)=F\left(\beta_{0}+\beta_{1} P D I_{i j}+\sum \beta_{k} \text { Other }_{\text {Variables }} j+\varepsilon_{i j}\right)
\end{aligned}
$$

\section{Dependent variables}

The dependent variable ICMW in model (1) equals one if sample firm $i$ reports a material weakness in year $j$ and zero otherwise. In models (2) and (3), the dependent variable Misstate equals one if sample firm $i$ 's financial statements for fiscal year $j$ are restated later in our sample period and zero otherwise.

Independent variables

For model (1), we test whether the likelihood of disclosing an ICMW is affected by a firm's connection through an audit committee member to another firm that previously disclosed a material weakness. We begin by classifying a sample firm as a disclosing firm if it reports an ICMW pertaining to period $t$. We then define a disclosing firm's post-disclosure period as the subsequent three years, $t+1$ to $t+3$, and its pre-disclosure period as $t-2$ to $t$. We note that in cases where the disclosing firm reports an ICMW in consecutive years, the post-disclosure period is longer because it would combine the post-disclosure periods for all the weaknesses. For instance, if the disclosing firm reports an ICMW in periods $t$ and $t+1$, the combined post-disclosure period would be $t+1$ to $t+4$. Thereafter, we refer to other sample firms linked to the disclosing firm as connected firms. Formally, we code our main independent variable for model (1), Post

Disclosure Interlock (PDI hereafter), equal to one if, in a given year $j$, a sample firm has an audit

This article is protected by copyright. All rights reserved. 
committee member who concurrently serves on the board of a disclosing firm and year $j$ occurs during the disclosing firm's post-disclosure period. For all other firm-year observations, PDI equals zero.

Figure 1 provides an illustration of how PDI is constructed. Consider the following example. Assume Firm A reports a material weakness (ICMW) for 2009 so its post-disclosure period is 2010-2012. Next, assume that Firm B has an audit committee member who concurrently serves on Firm A’s board during the 2010-2012 period. Thus, Firm B is the connected firm. This implies that, for Firm B, PDI is coded one in years 2010, 2011, and 2012. For all other years, PDI for Firm B is coded zero. ${ }^{6} \mathrm{H} 1$ predicts that $\beta_{1}<0$; Firm B’s likelihood of reporting an ICMW is lower during 2010-2012 than in any other year.

For model (2), we test whether the likelihood of having a misstatement is affected by a firm's connection through an audit committee member to another firm that previously restated its financial statements. Thus, we define the independent variable of interest as PDI-Restate rather than $P D I$ (i.e., the disclosing firm is disclosing a financial restatement). $\mathrm{H} 2$ predicts that $\beta_{1}<0$; a firm is less likely to have a misstatement that is later restated if it is connected to a firm that previously restated its financial statements.

For model (3), we test whether the likelihood of having a misstatement is affected by a firm’s connection through an audit committee member to another firm that previously disclosed an ICMW. Thus, we define the dependent variable, Misstate, as in model (2) and the independent

\footnotetext{
${ }^{6}$ In this example, if the disclosing firm, Firm A, reports an ICMW in years 2008 and 2009, its total post-disclosure period would be 2009-2012. Then for the connected firm, Firm B, PDI would be coded one for the years 2009-2012.
} 
variable, $P D I$, as in model (1). H3 predicts that $\beta_{1}<0$; a firm is less likely to disclose a financial restatement if it is connected to a firm that previously disclosed a material control weakness.

\section{Other independent variables}

We follow prior literature when identifying other independent variables that may affect a sample firm's likelihood of reporting an ICMW. We use the same controls for models (2) and (3) because factors that affect the probability of an ICMW disclosure typically also affect the likelihood of a misstatement (Abbot et al. 2004; DeFond and Jiambalvo 1991). We organize these independent variables into three categories: firm-related characteristics, governance-related characteristics, and other controls.

Firm characteristics. Prior literature suggests that the likelihood of an ICMW disclosure or a misstatement is affected by firm size and differences in operating conditions (Ashbaugh-Skaife et al. 2008; Doyle et al. 2007; Schrand and Zechman 2012). Firm size is measured as the log of market capitalization (Market Cap). Firm age (Firm Age) represents the age of the firm in years. Growth is measured as the year-over-year change in firm sales. Loss is included as an indicator variable coded one if the firm's income before extraordinary items is negative in the current or prior year and zero otherwise. Reverse $Z$ is measured as the reverse decile ranking of the firm's Altman Z score. Foreign Currency Trans is an indicator variable coded one if the firm has a foreign currency translation for the current year and zero otherwise. Restructure is an indicator variable coded one if the firm has a restructuring during the year and zero otherwise. We also 
control for whether a firm issued a restatement of its financial statements within the prior three years (Prior Restatement).

Governance characteristics. We control for various characteristics of boards and audit committees because prior literature suggests that corporate governance plays an important monitoring role, which could affect the likelihood of an ICMW disclosure or a misstatement (Abbot et al. 2004; Krishnan 2005; Vafeas 2005). In particular, we control for the presence of independent directors (Percent Outsiders), the size of the board (Board Size), the size of the audit committee of the board (AC Size), the total number of directorships held by audit committee members (AC Directorship), recent auditor changes (Auditor Change), and whether the firm employs a Big 4 auditor (Big 4).

Other controls. Because $\mathrm{H} 1$ - H3 rely on the argument that board networks are a primary source of information and insights about control practices and events surrounding financial restatements, we control for the possibility that other inter-firm connections are important sources of information as well (Haunschild and Beckman 1998). For example, we consider the possibility that firms that operate in the same industry likely employ similar control practices and face comparable control problems. Accordingly, we include Post-Disclosure Link-Industry, an indicator variable that equals one if a firm shares a 4-digit SIC industry with a disclosing firm during the disclosing firm's post-disclosure period. We also consider the possibility that firms absorb insights concerning an ICMW disclosure or a financial restatement via a shared auditor. We control for auditor links via an indicator variable, Post-Disclosure Link-Auditor, which takes 
the value of one if a firm shares a common audit office with a disclosing firm during the disclosing firm's post-disclosure period. We focus on links through audit offices because Lennox and Li (2014) suggest that the audit office is a more likely mechanism for information spillover. For model (1), Post-Disclosure Link-Industry and Post-Disclosure Link-Auditor are calculated based on connections to a firm that previously disclosed an ICMW, while in models (2) and (3), these variables are based on connections to a firm that previously disclosed a financial restatement.

We also include Total Interlocks, measured as the number of other firms a sample firm is connected with through shared directors, to control for the possibility that firms linked with more firms may be more likely to be connected to a firm that previously disclosed an ICMW (or a restatement). Finally, we control for industry (SIC 2-digit) and year fixed effects and calculate standard errors in all our tests by clustering at the firm level. The marginal effect of the coefficients is presented in each model.

\section{Descriptive statistics}

Table 1 provides descriptive statistics for our sample. Panel A shows that ICMW has a mean of 3.8 percent, which translates to 350 firm-year observations with ICMW disclosures. Correspondingly, Misstate is 5.5 percent of the sample firm-year observations, which translates to 506 misstatements. These percentages are lower than in prior internal control and financial restatement studies because our sample requires director-related data from ISS which covers 
larger firms that tend to report fewer ICMW (Doyle et al. 2007) and restatements. ${ }^{7}$ Consistent with ISS's focus on larger firms, 94 percent of firms in our sample are audited by the Big 4, and the median firm-year in our sample has a market capitalization of \$2.1 billion, a figure significantly larger than the median COMPUSTAT firm in our sample period, which is about \$200 million.

Table 1, panel A shows that 9.5 percent of our sample has an audit committee member who also serves on the board of an ICMW-disclosing firm during its post-disclosure period (i.e., PDI $=1$ ) and that PDI-Restate has a mean of 15.8 percent.

Table 1, panel B reveals that ICMW and PDI are significantly negatively correlated, which provides preliminary support for $\mathrm{H} 1$ that connecting directors with prior ICMW disclosure experience reduce the probability of reporting an ICMW. Similarly, Table 1, panel B reveals that Misstate and PDI-Restate are negatively correlated, which provides initial support for $\mathrm{H} 2$. In contrast, there is no preliminary evidence to support H3; Misstate and PDI are not correlated at the univariate level.

\section{Results}

\section{Main results}

Table 2 presents the results of estimating models (1) - (3). The coefficients represent the marginal effects of each variable included in the logit regressions. In column 1 , where ICMW is the dependent variable, $P D I$ is negative and statistically significant (z-stat: -2.14$)$. This supports

\footnotetext{
${ }^{7}$ Before imposing the requirement that the sample observations have director-related data from ISS, ICMW disclosures are 6.9 percent of the sample drawn from Audit Analytics. This is comparable with the 6.7 percent and 8.8 percent figures reported in Gordon and Wilford (2012) and Klam et al. (2012).
} 
H1 and implies that, for the average sample firm, a board connection reduces the likelihood of reporting an ICMW by 0.9 percent. Given a sample-wide average ICMW probability of 3.8 percent, a 0.9 percent reduction (to 2.9 percent) represents compelling evidence that ICMW disclosures under the mandatory provisions of SOX generate a significant spillover on connected firms. ${ }^{8}$

Table 2, column 1 shows that other inter-firm connections, such as operating in the same industry or sharing an auditor, have no discernable effects on the likelihood of reporting an ICMW. The absence of an auditor effect suggests that auditors are not a mechanism for transmission of information about internal controls. In turn, the absence of an industry effect implies that merely operating in the same industry is not sufficient to affect the internal controls of connected firms, even though firms operating in the same industry often confront similar internal control issues. ${ }^{9}$ Lastly, we note that the significance of the coefficients on many of the firm- and governance-related variables in column 1 are consistent with those found in prior internal control studies (e.g., Ashbaugh-Skaife et al. 2008; Doyle et al. 2007).

In Table 2, column 2, we present the results for model (2). When Misstate is the dependent variable, PDI-Restate is negative and statistically significant (z-stat: -1.96$)$. This supports our

\footnotetext{
${ }^{8}$ Our independent variable PDI is based on the assumption that an audit committee member of a connected firm is best positioned to initiate the spillover. In untabulated results, we calculate an alternative interlock variable where the connecting director is not on the audit committee of the connected firm. We find that if a connecting director is not on the audit committee, then he/she has no discernable effect on a connected firm's likelihood of reporting an ICMW.

${ }^{9}$ We also consider the impact of inter-firm connections that arise because a disclosing firm and a focal firm belong to the same corporate group (e.g., have the same parent company or ultimate parent company). In unreported tests, we find our results are unaffected if we exclude 63 firm-year observations where such inter-firm connections are present.
} 
second hypothesis and implies that, for the average sample firm, a board connection reduces the likelihood of reporting a financial restatement by 0.9 percent.

Taken together, the results in columns 1 and 2 of Table 2 suggest that connecting directors with prior ICMW disclosure or financial restatement experience use that experience to influence their firms' behaviors. However, as noted in section 2, directors' influence on firms can manifest in two ways. For instance, it can be argued that connecting directors have a positive influence on firms because they bring valuable information to the audit committee and improve their firms' internal control and financial reporting practices. But it is also possible that connecting directors use their experience superficially and ensure that firms under-report their shortcomings without any attendant improvements in underlying practices. Unfortunately, because we observe control weaknesses and misstatements only when firms publicly disclose them, we cannot empirically distinguish whether the spillover is superficial or has a real positive effect on firm practices.

In column 3 of Table 2, we present the results for model (3). With Misstate as the dependent variable, $P D I$ is negative but insignificant (z-stat: -0.21 ). If we interpret $\mathrm{H} 1$ to suggest that connecting directors use their prior ICMW disclosure experience to improve their firms' internal controls, then we would expect financial reporting quality to improve eventually as well. The insignificant coefficient for PDI in model (3) implies that director connections to ICMWdisclosing firms have no effect on financial reporting quality, at least as measured by the likelihood of financial restatements. The insignificant coefficient for PDI also implies that connecting directors do not use their prior ICMW disclosure experience to under-report financial 
restatements. However, the statistically insignificant coefficient could also be attributed to a lack of power in the test because there are only 40 observations where PDI and Misstate both equal one.

Taken together, the findings of this section suggest that public disclosure of adverse practices or events generates a spillover for connected firms. Specifically, we provide evidence in support of our first hypothesis that one firm's material weakness disclosure under section 404 deters a similar future disclosure at a connected firm, but that this effect occurs only when the connection is through an audit committee member. Moreover, while our focus is on the spillover effects of ICMW disclosures, evidence of a comparable spillover when the public disclosure is about financial restatements hints at a more general finding: Public disclosures of a broad class of adverse events can have a deterrence effect on other firms. Although we suspect these are positive spillovers due to improvements in firms' internal control and financial reporting practices, we acknowledge that the spillover may be superficial in the sense that control weaknesses and financial restatements are under-reported.

\section{Cross-sectional tests}

In this section, we conduct two cross-sectional tests to identify conditions under which spillovers from ICMW disclosures are more clearly evident. We organize our tests along two dimensions: (i) the strength of a connecting director's experience at the disclosing firm, and (ii) the magnitude of information about the underlying weakness that a connecting director can potentially convey. 


\section{Strength of connecting director's experience}

Our first hypothesis is based on the assumption that connecting directors convey information and insights about their ICMW experiences to connected firms. Therefore, we expect the spillover to be more clearly evident when a connecting director's experience at the disclosing firm allows him/her to more fully witness and internalize the events surrounding the disclosure. We measure the strength of a connecting director's experience in three ways: the director's incumbency on the disclosing firm's board, the director's service on the disclosing firm's audit committee, and the director's experience with remediation at the disclosing firm.

We label a connecting director as an incumbent if that director was on the board of the disclosing firm before the disclosure. Because an incumbent connecting director at the disclosing firm would have experienced the circumstances leading up to the disclosure, the disclosure itself, and the potential remediation efforts, we expect such a connecting director to have salient insights about the entire sequence of events surrounding the disclosure that can be readily conveyed to the connected firm's audit committee. Hence, we predict that spillovers are more clearly evident when a connecting director is an incumbent director on the disclosing firm's board rather than a director appointed after the disclosure.

Our second measure of a connecting director's experience is service on the disclosing firm's audit committee. Because the audit committee handles the fallout of the ICMW disclosure, we expect service on the disclosing firm's audit committee provides a director more firsthand information about the consequences and/or remediation efforts of the disclosing firm, which can 
be conveyed to and used by the connected firm. Hence, we expect spillovers to be more clearly evident when connecting directors serve on the disclosing firm's audit committee. Our third proxy, whether ICMWs have been remedied, assumes that a director who experiences the remediation efforts at a disclosing firm has more insights about how to improve and maintain effective internal controls as well as more information about the costs of such remediation efforts.

We measure incumbency by subdividing the $P D I$ variable into two mutually exclusive variables based on whether the connecting director was an incumbent on the disclosing firm's board before the ICMW disclosure. PDI-Incumbent (New) equals one if PDI equals one and the connecting director joined the board of the disclosing firm before (after) the disclosing firm's disclosure. Thus, the connecting director for PDI-Incumbent is on the disclosing firm's board before and after the disclosure while the director for PDI-New joined the disclosing firm after the disclosure. ${ }^{10}$ To examine the effect of a director's service on a disclosing firm's audit committee, we decompose $P D I$ into two variables: $P D I$-(Non) AC is coded one if $P D I$ equals one and the connecting director is (not) an audit committee member at the disclosing firm. For our sample firms, we assume remediation to have occurred if a firm reports an ICMW one year but does not report an ICMW in the subsequent year. We then decompose PDI into two mutually exclusive

\footnotetext{
${ }^{10}$ For an illustration, consider Figure 1 where an audit committee member of Firm B is concurrently connected to an ICMW-disclosing Firm A in years 2010 through 2012. If we assume that the connecting director has also been on Firm A's board since at least 2009, then for Firm B, PDI-Incumbent would be coded one for years 2010, 2011, and 2012, respectively. However, if we assume that the connecting director joined Firm A's board after 2010, then PDIIncumbent would be coded zero and PDI-New would be coded one for years 2010-2012.
} 
variables based on whether the disclosing firm remedied its ICMWs: PDI-(Non) Remediation is equal to one if $P D I$ equals one and the disclosing firm has (not) remedied its ICMWs.

Table 3 provides preliminary evidence of the $P D I$ decomposition. Whereas 9.5 percent of the sample where PDI equals one are reported earlier in Table 1, 8.1 percent are incumbent directors on the disclosing firms' boards (PDI-Incumbent), 5.4 percent are directors who serve on the disclosing firm audit committee (PDI-AC), and 7.9 percent of directors have experienced remediation at the disclosing firm (PDI-Remediation). Importantly, we note that all three measures of the strength of a connecting director's experience are associated with fewer incidences of ICMW, which provides preliminary evidence that the spillover is more evident when a connecting director has more relevant experience with the disclosing firm.

Table 4 provides formal tests of the effects of a connecting director's experience. In column 1, we find that PDI-Incumbent has a negative and significant coefficient (z-stat: -3.25) while PDI-New is statistically insignificant. In column 2, we find that $P D I-A C$ has a negative and significant coefficient (z-stat: -2.48) while PDI-Non AC has an insignificant coefficient. In column 3, PDI-Remediation (z-stat: -2.50) is negative and significant and PDI-Non Remediation is statistically insignificant. Taken together, these results suggest that the spillover is more clearly evident when the connecting director has comprehensive experience with the disclosing firm. 


\section{Magnitude of ICMW information}

If connecting directors convey information and insights about their ICMW disclosure experiences to connected firms, then we expect spillovers to be more clearly evident when the information conveyed about the underlying ICMW is more substantial. ${ }^{11}$ We consider the pervasive nature of the disclosed ICMW as a proxy for the magnitude of the information. Pervasive ICMWs pertain to a firm's overall internal control environment or susceptibility to management override and they are more substantive and harder to remedy (Goh 2009). Following prior literature, we classify such ICMWs as "entity-wide” using descriptions provided by Audit Analytics (Bedard et al. 2012). We then decompose PDI into two mutually exclusive variables, PDI Entity Weakness and PDI Non-Entity Weakness, based on whether the disclosing firm's ICMW is classified as entity-wide.

As shown in Table 3, the mean of PDI Entity Weakness is 4.3 percent and is generally associated with fewer incidences of ICMW. This is consistent with our expectation that the magnitude of information available about the underlying weakness has an important effect on the connected firm's disclosures.

In Table 4, column 4, the coefficient on PDI Entity Weakness is negative and significant (zstat: -4.71) while the coefficient on PDI-Non Entity Weakness is insignificant. This provides evidence that the spillover is more evident when the information conveyed about the underlying weakness is more substantial.

\footnotetext{
${ }^{11}$ As in $\mathrm{H} 1$ and H2, there are two reasons a spillover might manifest in this test: knowledge of the substance of the underlying ICMW can spur the connected firm to improve its internal controls, or sway the firm to under-report its ICMWs.
} 


\section{Additional analysis}

In this section, we provide a number of additional tests and sensitivity analyses to illustrate the robustness of our results and address concerns about alternative interpretations.

\section{Director quality}

An important alternative explanation for our finding that $P D I$ is negatively associated with ICMW disclosures rests on the argument that $P D I$ measures the inherent high quality of connecting directors rather than their information and insights from prior experiences. We address this concern several ways.

First, we note that our main finding of a negative association between ICMW and PDI in Table 2 is conditional on a commonly used indicator of director quality, AC Directorships (e.g., Fama and Jensen 1983). Although PDI and AC Directorships are positively associated at the univariate level (Table 1, panel B), the effect of PDI on ICMW in Table 2 is clearly incremental to director quality.

Second, we control for the presence of an individual high-quality director on the audit committee of a sample firm. ${ }^{12}$ We code High Quality Director equal to one if the sample firm has an audit committee member whose total number of board seats is above the sample median of all directors in the sample and zero otherwise. In Table 5, column 1, we show that PDI retains its negative coefficient while the coefficient on High Quality Director is statistically insignificant. Hence, to the extent that the number of board appointments held by a director is a

\footnotetext{
${ }^{12}$ In contrast, AC Directorships measures the total number of board seats held by all audit committee members of a sample firm.
} 
reasonable indicator of his/her quality, the evidence again suggests that the effect of $P D I$ on ICMW is capturing an effect beyond quality.

Finally, we focus on the subsample of observations without director turnover to mitigate the concern that PDI merely proxies for director quality. If firms systematically replace low-quality directors with high-quality ones, then the variation in director quality in the no-turnover sample should be minimal. Hence, to the extent that PDI retains its association with ICMW, it alleviates the concern that the association is due to PDI serving as a proxy for director quality. ${ }^{13} \mathrm{We}$ therefore rerun model (1) on the no-turnover subsample. In Table 5, column 2, we continue to find that $P D I$ retains a negative and significant coefficient at the 5 percent level which again implies that the effect of PDI on ICMW is capturing an effect beyond quality.

Altogether, our sensitivity tests in this section help mitigate the concern that PDI measures the inherent high quality of connecting directors rather than their information and insights from prior experiences. However, because director quality is not observable in all its dimensions, we acknowledge that our tests may not fully disentangle the effect of director quality on PDI.

\section{Director selection}

Our results are also susceptible to the concern that “director selection” or matching of directors with firms explains our findings. For instance, if firms appoint directors with prior material weakness experience as a precaution, or if directors with prior material weakness experience only seek future board appointments at firms with strong internal controls, then our

\footnotetext{
${ }^{13}$ The (in)significant coefficient on PDI-(New)-Incumbent in Table 4 also helps to address the concern that firms systematically replace low-quality directors with newer, higher quality ones by showing that our findings are only attributable to incumbent directors of the disclosing firm, and not to new ones.
} 
finding of a negative association between $P D I$ and ICMW may be attributed to director selection rather than directors' prior experiences with ICMW disclosures. One way we address this issue is to redefine PDI to exclude post-ICMW disclosure board appointments that may be most affected by director selection concerns. In particular, we define PDI-Alternative equal to one if PDI equals one and the connecting director was on the board of the connected firm before the disclosing firm's disclosure. Table 6, panel A presents our results. Consistent with our finding in Table 2 column 1, we find that PDI-Alternative is significantly negative ( $t$-stat: -2.40$)$. Hence, we suggest that director selection is unlikely to be a major concern.

We also present additional evidence about director selection by examining how directors’ prior experiences with ICMW disclosures affect their probability of new board appointments. Specifically, we define New Dir equal to one if an audit committee director is appointed to a new board in a given year and zero otherwise and let Post Disclosure indicate if the director experienced an ICMW in the prior three years at any of his/her directorships. In Table 6, panel B, we present a regression of New Dir on Post Disclosure controlling for director age, number of directorships, the average firm performance (stock returns) of the director's other appointments and various other controls. We find that Post Disclosure has a negative and significant coefficient at the 1 percent level, suggesting that firms are less likely to appoint a director once that director becomes associated with an ICMW disclosure. More importantly, the evidence counters director selection concerns because it shows that firms tend to avoid rather than seek directors with prior ICMW disclosure experience. 


\section{Other sensitivity tests}

In this section, we conduct a number of additional sensitivity tests to address the robustness of our results for model (1). First, we repeat our main test but drop a firm from the analysis after it reports an ICMW. This reduces the number of observations and controls for the fact that firms tend to remedy their ICMWs shortly after the disclosure. The results presented in Table 7, column 1 confirm our main finding in Table 2, column 1.

Second, we examine whether the likelihood of reporting an ICMW depends on the passage of time in some way. For instance, we note a steady decrease in the instances of ICMW disclosures during our sample period. We use a discrete-time logistic model which estimates the probability that a firm reports a material weakness in time $t$, given that it has not yet reported one thus far (Allison 1984). We use the same modified dependent variable used in column 1 . The results, presented in column 2 of Table 7, suggest the PDI coefficient is negative and statistically significant (z-stat: -2.85), consistent with our main finding in Table 2.

Third, we test our model (1) on two subsamples, 2004-2007 and 2008-2012, to address concerns that firms reported more weaknesses in the earlier years than in later years of our sample period (Gordon and Wilford 2012). We choose 2007 as the cutoff year because the biggest decline in ICMW disclosures in our sample occurs in 2007 and because 2007 is approximately the midpoint of our sample period. Table 7, columns 3 and 4 present this test. Consistent with the results in Table 2, column 1, we find that PDI has a negative and statistically 
significant coefficient for both subsamples, indicating that the timing of firms' ICMW

disclosures during the sample period does not affect our results.

Fourth, we consider an alternative definition of how firms are connected to an ICMWdisclosing firm. Instead of $P D I$, we use the number of links to a disclosing firm by a connecting director scaled by total interlocks to control for the possibility that the relative amount of internal control information could impact the firm's decision making. The results reported in Table 7 column 5 suggest that our results are robust to this alternative measure. ${ }^{14}$

\section{Reconciling with prior studies}

Our finding that the public disclosure of an ICMW (or financial restatement) has the potential to create a positive spillover stands in contrast with other papers that document a negative spillover from board connections. For example, Chiu et al. (2013) find that firms are more likely to engage in aggressive financial reporting if they share a director with a firm that also engages in aggressive financial reporting, and Bizjack et al. (2009) find that option backdating spreads among firms with shared directors. Although both of these studies show that negative practices spread between connected firms, in both cases, the studied behavior is privately observed.

An important feature of our setting is the public nature of ICMW disclosures. We argue that public disclosures of negative practices reduce the chances of imitation and likely serve as a deterrent. In particular, we argue that when the consequences and potential remedies of ICMW

\footnotetext{
${ }^{14}$ We also create an interlock variable that excludes year one from the post-disclosure period. In unreported tests, defining $P D I$ for only years two and three of the post-disclosure period does not affect our results. We also create three separate PDI variables for each year of the post-disclosure period. In unreported tests, we find that the PDI variable for years one and two are statistically insignificant, but that the PDI for year three is negative and statistically significant.
} 
disclosures become apparent, the cost-benefit tradeoff likely shifts in favor of improving internal controls. Thus, a fundamental difference between our setting and the settings of Chiu et al. (2013) and Bizjack et al. (2009) is the public nature of the disclosure.

To bolster our argument that the public nature of an ICMW disclosure is what drives the spillover, we revisit our test of model (1) but with board connections that are present in an ICMW disclosing firm's pre-disclosure period, a period that is more akin to the non-public settings of Chiu et al. (2013) and Bizjack et al. (2009). We set an indicator variable PreDisclosure Interlock equal to one if a firm has an audit committee member who concurrently serves on the board of another firm during that firm's pre-disclosure period. Thus unlike PDI in Table 2, column 1, Pre-Disclosure Interlock reflects board connections with a firm whose internal controls are weak but yet to be acknowledged as such publicly. Table 8 provides the results. Consistent with prior findings of negative contagion, we find that the coefficient on PreDisclosure Interlock is significantly positive at the 1 percent level. This reconciles our results with prior contagion studies and suggests that weak control practices are contagious when the costs, consequences and potential remedies of ICMW disclosures are not readily apparent.

\section{Conclusion}

We find that firms are less likely to disclose internal control material weaknesses if they are connected, through an audit committee member, to a firm that previously disclosed its own internal control material weakness. We find a similar spillover effect for financial restatements. We focus on shared directors who are audit committee members because board members are 
privy to information and insights within their board networks and because audit committee members are specifically charged with overseeing internal controls and financial reporting. Our findings underscore the importance of audit committees in shaping firms' internal control and financial reporting practices. In contrast to connecting audit committee directors, we find no evidence that other inter-firm connections (e.g., having the same auditors or operating in the same industry) have similar effects.

We also find that a connected firm's lower likelihood of disclosing an internal control material weakness is evident only when the connecting director has relevant experience with the weakness-disclosing firm and/or when the director has substantial information about the underlying control weakness. For example, we find that the likelihood of disclosing an internal control material weakness is lower only when the connecting director is an incumbent director on the disclosing firm's board, serves on the disclosing firm's audit committee, or when the disclosed material weakness is considered pervasive.

Our findings suggest that directors' experiences with other firms are an important source of information about the costs of operating with weak internal controls and/or having low-quality financial reporting as well as the potential benefits of remedying such practices. One interpretation is that directors use this information constructively to improve their firms' internal control practices and financial reporting quality. This highlights the importance of public disclosures such as SOX as a source of positive spillovers, a benefit of SOX that has not been well recognized in the literature. However, because firms' control practices or the quality of their 
financial reporting are not directly observable, an alternative interpretation holds that directors use their prior experiences to ensure that firms under-report their deficiencies to the public. Hence, a fruitful avenue for future research would be to better understand circumstances where mandated public disclosures encourage more misreporting or where such disclosures serve as a deterrent for others and generate positive spillovers.

\section{References}

Abbott, L.J., S. Parker, and G.F. Peters. 2004. Audit committee characteristics and restatements. Auditing: A Journal of Practice \& Theory 23 (1): 69-87.

Allison, P. D. 1984. Event History Analysis. Beverly Hills, CA: Sage.

Altman, E.I. 1968. Financial ratios, discriminant analysis and the prediction of corporate bankruptcy. The Journal of Finance 23 (4): 589-609.

Ashbaugh-Skaife, H., D.W. Collins, and W.R. Kinney Jr. 2008. The discovery and reporting of internal control deficiencies prior to SOX-mandated audits. Journal of Accounting and Economics 44 (1-2): 166-192.

Ashbaugh-Skaife, H., D.W. Collins, W.R. Kinney Jr., and R. LaFond. 2009. The effect of SOX internal control deficiencies on firm risk and cost of equity. Journal of Accounting Research 47 (1): 1-42.

Bandura, A. 1965. Influence of models' reinforcement contingencies on the acquisition of imitative responses. Journal of Personality and Social Psychology 1 (6): 589-595.

Bandura, A. 1971. Social Learning Theory. New York: General Learning Press.

Becker, G. S. 1968. Crime and punishment: An economic approach. Journal of Political Economy 76: 169-217.

Bedard, J.C., R. Hoitash, U. Hoitash, and K. Westermann. 2012. Material weakness remediation and earnings quality: A detailed examination by type of control deficiency. Auditing: A Journal of Practice \& Theory 31 (1): 57-78. 
Beneish, M.D., M.B. Billings, and L.D. Hodder. 2008. Internal control weakness and information uncertainty. The Accounting Review 83 (3): 665-703.

Bizjak, J., M. Lemmon, and R. Whitby. 2009. Option backdating and board interlocks. Review of Financial Studies 22 (11): 4821-4847.

Cai, Y., D.S. Dhaliwal, Y. Kim, and C. Pan. 2014. Board interlocks and the diffusion of disclosure policy. Review of Accounting Studies 19 (3): 1086-1119.

Chiu, P., S. Teoh, and F. Tian. 2013. Board interlocks and earnings management contagion. The Accounting Review 88 (3): 915-944.

DeFond, M., and J. Jiambalvo. 1991. Incidence and circumstances of accounting errors. The Accounting Review 66 (3): 643-655.

DeFond, M. and C. Lennox. 2017. Do PCAOB inspections improve the quality of internal control audits? Journal of Accounting Research 55 (3): 591-627.

DeZoort, F. 1997. An investigation of audit committees’ oversight responsibilities. Abacus 33 (2): 208-227.

Dhaliwal, D., C. Hogan, R. Trezevant and M. Wilkins. 2011. Internal control disclosures and cost of debt. The Accounting Review 86 (4): 1131-1156.

Doyle, J., W. Ge, and S. McVay. 2007. Determinants of weaknesses in internal control over financial reporting. Journal of Accounting and Economics 44 (1): 193-223.

Fama, E.F., and M.C. Jensen. 1983. Separation of ownership and control. The Journal of Law \& Economics 26 (2): 301-325.

Files, R., E. P. Swanson, and S. Tse. 2009. Stealth Disclosure of Accounting Restatements. The Accounting Review 84 (5): 1495-1520.

Gino, F., S. Ayal, and D. Ariely. 2009. Contagion and differentiation in unethical behavior: The effect of one bad apple on the barrel. Psychological Science 20 (3): 393-398.

Goh, B.W. 2009. Audit committees, boards of directors, and remediation of material weaknesses in internal control. Contemporary Accounting Research 26 (2): 549-579.

Gordon, L., and A.L. Wilford. 2012. An analysis of multiple consecutive years of material weaknesses in internal control. The Accounting Review 87 (6): 2027-2060.

This article is protected by copyright. All rights reserved. 
Haunschild, P., and C. M. Beckman. 1998. When do interlocks matter?: Alternate sources of information and interlock influence. Administrative Science Quarterly 43 (4): 815844.

Hochberg, Y.V., P. Sapienza, and A. Vissing-Jorgensen. 2009. A lobbying approach to evaluating the Sarbanes-Oxley Act of 2002. Journal of Accounting Research 47 (2): 518-583.

Hoitash, U., R. Hoitash, and J.C. Bedard. 2008. Internal control quality and audit pricing under the Sarbanes-Oxley Act. Auditing: A Journal of Practice \& Theory 27 (1): 105-126

Iliev, P. 2010. The effect of SOX Section 404: Costs, earnings quality, and stock prices. The Journal of Finance 65 (3): 1163-1196.

Klam, B.K., K.W. Kobelsky, and M.W. Watson. 2012. Determinants of the persistence of internal control weaknesses. Accounting Horizons 26 (2): 307-333.

Krishnan, J. 2005. Audit committee quality and internal control: An empirical analysis. The Accounting Review 80 (2): 649-675.

Lennox, C. and B. Li. 2014. Accounting misstatements following lawsuits against auditors. Journal of Accounting and Economics 57(1): 58-75.

Lennox, C. and B. Li. 2017. Lawsuit outcomes and the deep pockets of Big N audit firms. Working Paper, University of Southern California and City University of Hong Kong.

Leuz, C., A. Triantis, and T.Y. Wang. 2008. Why do firms go dark? Causes and economic consequences of voluntary SEC deregistrations. Journal of Accounting and Economics 45 (2-3): 181-208.

Linck, J.S., J.M. Netter, and T. Yang. 2009. The effects and unintended consequences of the Sarbanes-Oxley Act on the supply and demand for directors. Review of Financial Studies 22 (8): 3287-3328.

Mizruchi, M. 1996. What do interlocks do? An analysis, critique, and assessment of research on interlocking directorates. Annual Review of Sociology 22: 271-298. 
Rice, S.C., and D.P. Weber. 2012. How effective is internal control reporting under SOX 404? Determinants of (non-)disclosure of existing material weakness. Journal of Accounting Research 50 (3): 811-844.

Schrand, C.M. and S.L. Zechman. 2012. Executive overconfidence and the slippery slope to financial misreporting. Journal of Accounting and Economics 53(1-2): 311-329.

Scholz, J.T. 1984. Cooperation, deterrence, and the ecology of regulatory enforcement. Law and Society Review 18 (2): 179-224.

Vafeas, N. 2005. Audit committees, boards, and the quality of reported earnings. Contemporary Accounting Research 22 (4): 1093-1112 
Figure 1: Post-Disclosure Interlock

Disclosing Firm

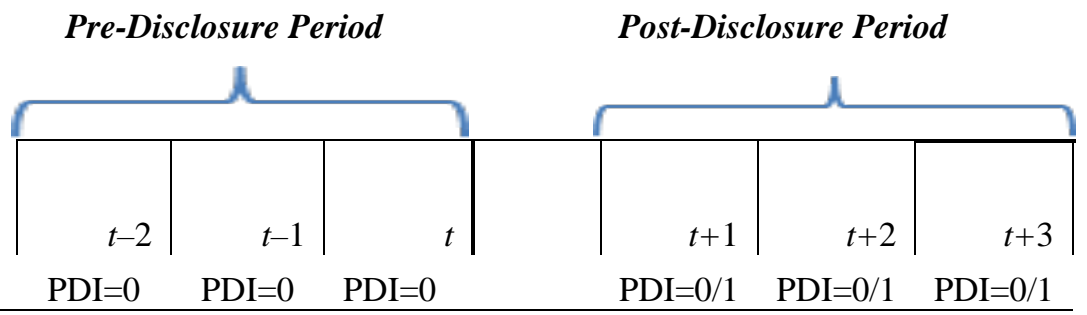

\section{Connected firm}

$\mathrm{PDI}=0 \quad \mathrm{PDI}=0 \quad \mathrm{PDI}=0$

$\mathrm{PDI}=0 / 1 \quad \mathrm{PDI}=0 / 1 \quad \mathrm{PDI}=0 / 1$

A disclosing firm discloses an internal control material weakness pertaining to year $\mathrm{t}$, which makes its postdisclosure period year $t+1, t+2$, and $t+3$. A connected firm is any sample firm that is connected to the disclosing firm through an audit committee member during the disclosing firm's post-disclosure period. PDI equals one if a connected firm's audit committee member concurrently serves on the disclosing firm's board in a year that is during the disclosing firm's post-disclosure period $(t+1, t+2$, and $t+3)$. In the post-disclosure period, a connection between the connected and disclosing firms would make $P D I$ equal one. If there is no connection in the post-disclosure period between the two firms, PDI equals zero. 


\begin{tabular}{|c|c|}
\hline \multicolumn{2}{|l|}{$\begin{array}{l}\text { Appendix } \\
\text { Variable definitions }\end{array}$} \\
\hline Variable & Definition \\
\hline ICMW & $\begin{array}{l}\text { Coded one if the firm reported a material weakness under SOX } 404 \text { and zero } \\
\text { otherwise. }\end{array}$ \\
\hline Misstate & $\begin{array}{l}\text { Coded one if a firm's current year financial reports are later restated during the } \\
\text { sample period and zero otherwise. }\end{array}$ \\
\hline PDI & $\begin{array}{l}\text { Coded one if a firm in year } j \text { has an audit committee member who concurrently } \\
\text { serves on the board of a disclosing firm in a year that is during the disclosing firm's } \\
\text { post-disclosure period; coded zero otherwise. The post-disclosure period is defined } \\
\text { as the three-year period following the disclosing firm's ICMW disclosure. }\end{array}$ \\
\hline PDI-Restate & $\begin{array}{l}\text { Coded one if a firm in year } j \text { has an audit committee member who concurrently } \\
\text { serves on the board of a disclosing firm that restated its financial statements in a year } \\
\text { that is during the disclosing firm's post-disclosure period; coded zero otherwise. The } \\
\text { post-disclosure period is defined as the three-year period following the disclosing } \\
\text { firm's restatement disclosure. }\end{array}$ \\
\hline $\begin{array}{l}\text { PDI-Incumbent } \\
\text { (PDI-New) }\end{array}$ & $\begin{array}{l}\text { Coded one if a firm in year } j \text { has an audit committee member who (i) concurrently } \\
\text { serves on the board of a disclosing firm in a year that is during the disclosing firm's } \\
\text { post-disclosure period and (ii) joined the disclosing firm's board before (after) the } \\
\text { time of its ICMW disclosure; coded zero otherwise. }\end{array}$ \\
\hline $\begin{array}{l}\text { PDI-AC } \\
(P D I-N o n A C)\end{array}$ & $\begin{array}{l}\text { Coded one if a firm in year } j \text { has an audit committee member who concurrently } \\
\text { serves on the audit committee of the board of a disclosing firm in a year that is } \\
\text { during the disclosing firm's post-disclosure period; coded zero otherwise. PDI-Non } \\
A C \text { is coded one if a sample firm in year } j \text { has an audit committee member who } \\
\text { concurrently serves on the board (but not on the audit committee) of a disclosing } \\
\text { firm in a year that is during the disclosing firm's post-disclosure period; coded zero } \\
\text { otherwise. }\end{array}$ \\
\hline $\begin{array}{l}\text { PDI-Remediation } \\
\text { (PDI-Non Remediation) }\end{array}$ & $\begin{array}{l}\text { Coded one if a firm in year } j \text { has an audit committee member who (i) concurrently } \\
\text { serves on the board of a disclosing firm in a year that is during the disclosing firm's } \\
\text { post-disclosure period and (ii) the disclosing firm remediated (did not remediate) its } \\
\text { weakness; coded zero otherwise. }\end{array}$ \\
\hline $\begin{array}{l}\text { PDI Entity Weakness } \\
\text { (PDI Non-Entity Weakness) }\end{array}$ & $\begin{array}{l}\text { Coded one if a firm in year } j \text { has an audit committee member who (i) concurrently } \\
\text { serves on the board of a disclosing firm in a year that is during the disclosing firm's } \\
\text { post-disclosure period and (ii) the disclosing firm's material weakness is (not) } \\
\text { classified an entity-wide weakness; coded zero otherwise. }\end{array}$ \\
\hline PDI-Alternative & $\begin{array}{l}\text { Coded one if a firm in year } j \text { has an audit committee member who (i) concurrently } \\
\text { serves on the board of a disclosing firm in a year that is during the disclosing firm's } \\
\text { post-disclosure period and (ii) was on the connected firm’s board before the } \\
\text { disclosing firm's ICMW disclosure; coded zero otherwise. }\end{array}$ \\
\hline Market Cap & Log of market capitalization. \\
\hline Firm Age & Age of the firm. \\
\hline Loss & $\begin{array}{l}\text { Coded one if the income before extraordinary items is less than zero in the current } \\
\text { year. }\end{array}$ \\
\hline Reverse Z & $\begin{array}{l}\text { Reverse decile rankings of the Altman Z Score, which is calculated following } \\
\text { Altman (1968): } 1.2^{*} \text { (Working Capital/Assets) }+1.4^{*} \text { (Retained Earnings/Assets) + } \\
\text { 3.3*(Earnings Before Income and Taxes/Assets) }+.6 * \text { (Market Value of }\end{array}$ \\
\hline
\end{tabular}


Equity/Assets) + .99*(Sales/Assets).

\begin{tabular}{|c|c|}
\hline Growth & The difference between sales in year $t$ and $t-1$ scaled by sales in $t-1$. \\
\hline Foreign Currency Trans & $\begin{array}{l}\text { Coded one if the firm had a foreign currency translation in the current year and zero } \\
\text { otherwise. }\end{array}$ \\
\hline Restructure & Coded one if the firm had a restructuring in the current year and zero otherwise. \\
\hline Prior Restatement & $\begin{array}{l}\text { Coded one if the firm issued a restatement of its financial statements in the prior } \\
\text { three years and zero otherwise. }\end{array}$ \\
\hline Percent Outsiders & Percentage of the independent directors on the board. \\
\hline Board Size & The log of board size. \\
\hline AC Size & The log of audit committee size. \\
\hline AC Directorships & $\begin{array}{l}\text { The log of one plus the total number of directorships held by audit committee } \\
\text { members. }\end{array}$ \\
\hline Auditor Change & Coded one if the firm had an audit change in the current year and zero otherwise. \\
\hline Big 4 & Coded one if the firm had a Big 4 Auditor in the current year and zero otherwise. \\
\hline $\begin{array}{l}\text { Post-Disclosure Link- } \\
\text { Industry }\end{array}$ & $\begin{array}{l}\text { Coded one if the firm shares an industry (SIC 4-digit) with a disclosing firm in a year } \\
\text { that is during the disclosing firm's post-disclosure period and zero otherwise. When } \\
\text { ICMW (Misstate) is the dependent variable, the disclosing firm for this variable } \\
\text { previously disclosed a material weakness (restatement). }\end{array}$ \\
\hline $\begin{array}{l}\text { Post-Disclosure Link- } \\
\text { Auditor }\end{array}$ & $\begin{array}{l}\text { Coded one if the firm shares a common audit office with a disclosing firm in a year } \\
\text { that is during the disclosing firm's post-disclosure period and zero otherwise. When } \\
\text { ICMW (Misstate) is the dependent variable, the disclosing firm for this variable } \\
\text { previously disclosed a material weakness (restatement). }\end{array}$ \\
\hline Total Interlocks & $\begin{array}{l}\text { The log of one plus the total interlocks where an interlock is the total number of } \\
\text { other firms a firm is connected with through a shared director. }\end{array}$ \\
\hline High Quality Director & $\begin{array}{l}\text { Coded one if the firm has an audit committee member whose total number of board } \\
\text { seats is above the sample median of total board seats for all directors in the sample; } \\
\text { coded zero otherwise. }\end{array}$ \\
\hline Pre-Disclosure Interlock & $\begin{array}{l}\text { Coded one if a firm has an audit committee member who concurrently serves on the } \\
\text { board of a disclosing firm in a year that is during that firm's pre-disclosure period, } \\
\text { which is defined as the three-year period leading up to the disclosing firm's ICMW } \\
\text { disclosure; coded zero otherwise. }\end{array}$ \\
\hline $\begin{array}{l}\text { Pre-Disclosure Link } \\
\text { Industry }\end{array}$ & $\begin{array}{l}\text { Coded one if a firm shares an industry (SIC 4-digit) with a disclosing firm in a year } \\
\text { that is during that firm's pre-disclosure period; coded zero otherwise. }\end{array}$ \\
\hline Pre-Disclosure Link Auditor & $\begin{array}{l}\text { Coded one if a firm shares a common audit office with a disclosing firm in a year } \\
\text { that is during that firm's pre-disclosure period; coded zero otherwise. }\end{array}$ \\
\hline New Dir & $\begin{array}{l}\text { Coded one if the director received a new appointment in a given year and zero } \\
\text { otherwise. This variable is used in the director selection model of Table 6B. }\end{array}$ \\
\hline Post Disclosure & $\begin{array}{l}\text { Coded one if the director experienced an ICMW disclosure in the past three years at } \\
\text { any of his/her firms; coded zero otherwise. This variable is used in the director } \\
\text { selection model of Table } 6 \text { panel B. }\end{array}$ \\
\hline Similar Size & $\begin{array}{l}\text { Coded one if the director sits on the board of a firm in the same size decile as the } \\
\text { prospective new firm; coded zero otherwise. This variable is used in the director } \\
\text { selection model of Table } 6 \text { panel B. }\end{array}$ \\
\hline Same Industry & $\begin{array}{l}\text { Coded one if the director sits on a board of a firm in the same industry as the } \\
\text { prospective new firm; coded zero otherwise. This variable is used in the director } \\
\text { selection model of Table } 6 \text { panel B. }\end{array}$ \\
\hline Same Region & $\begin{array}{l}\text { Coded one if the director sits on a board of a firm in the same region as the } \\
\text { prospective new firm; coded zero otherwise. This variable is used in the director }\end{array}$ \\
\hline
\end{tabular}


selection model of Table 6 panel B.

\begin{tabular}{ll}
\hline Age & $\begin{array}{l}\text { Age of the director. This variable is used in the director selection model of Table } 6 \\
\text { panel B. }\end{array}$ \\
\hline Avg Perf & $\begin{array}{l}\text { The average stock return of all of the director's firms. This variable is used in the } \\
\text { director selection model of Table } 6 \text { panel B. }\end{array}$ \\
\hline Directorships & $\begin{array}{l}\text { Number of board seats held by the director. This variable is used in the director } \\
\text { selection model of Table } 6 \text { panel B. }\end{array}$ \\
\hline
\end{tabular}
selection model of Table 6 panel B. 
Table 1: Descriptive statistics

Panel A: Dependent and independent variables

\begin{tabular}{lrrrr}
\hline Variable & Mean & P 25 & P 50 & P 75 \\
\hline Dependent variables & & & & \\
ICMW & 0.038 & 0.000 & 0.000 & 0.000 \\
Misstated & 0.054 & 0.000 & 0.000 & 0.000 \\
Independent variables & & & & \\
Post-Disclosure Interlock (PDI) & 0.095 & 0.000 & 0.000 & 0.000 \\
PDI-Restate & 0.158 & 0.000 & 0.000 & 0.000 \\
Firm characteristics & & & & \\
Market Cap & 7.809 & 6.735 & 7.671 & 8.743 \\
Age & 26.741 & 12.000 & 20.000 & 38.000 \\
Loss & 0.180 & 0.000 & 0.000 & 0.000 \\
ReverseZ & 3.684 & 2.000 & 3.000 & 5.000 \\
Foreign Currency Trans & 0.351 & 0.000 & 0.000 & 1.000 \\
Restructure & 0.400 & 0.000 & 0.000 & 1.000 \\
Growth & 0.097 & 0.000 & 0.079 & 0.169 \\
Prior Restatement & 0.120 & 0.000 & 0.000 & 0.000 \\
Governance characteristics & & & & \\
Percent Outsiders & 0.768 & 0.700 & 0.800 & 0.875 \\
Board Size & 9.148 & 8.000 & 9.000 & 11.000 \\
AC Size & 3.728 & 3.000 & 4.000 & 4.000 \\
AC Directorships & 5.594 & 4.000 & 5.000 & 7.000 \\
Auditor Change & 0.024 & 0.000 & 0.000 & 0.000 \\
Big 4 & 0.943 & 1.000 & 1.000 & 1.000 \\
Other controls & & & & \\
Post-Disclosure Link Auditor & 0.371 & 0.000 & 1.000 & 1.000 \\
Post-Disclosure Link Industry & 0.328 & 0.000 & 0.000 & 1.000 \\
Total Interlocks & 4.408 & 1.000 & 3.000 & 6.000 \\
\hline
\end{tabular}


Panel B: Correlation of selected variables

\begin{tabular}{|c|c|c|c|c|c|c|c|}
\hline & ICMW & Misstate & $P D I$ & PDI-Restate & $\begin{array}{l}\text { Market } \\
\text { Cap }\end{array}$ & $\begin{array}{l}\text { Prior } \\
\text { Restatement }\end{array}$ & $\begin{array}{l}\text { Percent } \\
\text { Outsiders }\end{array}$ \\
\hline Misstate & $0.266 * * *$ & & & & & & \\
\hline$P D I$ & $-0.035 * * *$ & -0.013 & & & & & \\
\hline PDI-Restate & $-0.044 * * *$ & $-0.043 * * *$ & $0.469 * * *$ & & & & \\
\hline Market Cap & $-0.104^{* * *}$ & $-0.069 * * *$ & $0.069 * * *$ & $0.134^{* * *}$ & & & \\
\hline Prior Restatement & $0.071^{* * *}$ & $-0.080 * * *$ & 0.017 & $0.022 * *$ & $-0.085 * * *$ & & \\
\hline Percent Outsiders & $-0.052 * * *$ & $-0.082 * * *$ & $0.069 * * *$ & $0.117 * * *$ & $0.167 * * *$ & $0.050 * * *$ & \\
\hline AC Directorships & $-0.059 * * *$ & $-0.043 * * *$ & $0.247 * * *$ & $0.351^{* * *}$ & $0.399 * * *$ & $-0.045^{* * *}$ & $0.287 * * *$ \\
\hline
\end{tabular}

Panel A provides descriptive statistics for the variables included in our main analysis. Board Size, AC Size, and AC Directorships are not log transformed in Panel A. Panel B provides the correlations among the main variables. ** and $* * *$ represent significance at the 5 percent and 1 percent levels using a two-tailed test. Variables are defined in the Appendix. 
Table 2: Effect of interlock with disclosing firm

\begin{tabular}{|c|c|c|c|c|}
\hline Variables & Prediction & $\begin{array}{c}(1) \\
I C M W\end{array}$ & $\begin{array}{c}(2) \\
\text { Misstate }\end{array}$ & $\begin{array}{c}\text { (3) } \\
\text { Misstate }\end{array}$ \\
\hline$P D I$ & - & $\begin{array}{c}-\mathbf{0 . 0 0 9} * * \\
(-2.141)\end{array}$ & & $\begin{array}{c}-0.001 \\
(-0.210)\end{array}$ \\
\hline PDI-Restate & - & & $\begin{array}{c}\mathbf{- 0 . 0 0 9 * *} \\
(-1.961)\end{array}$ & \\
\hline \multicolumn{5}{|l|}{ Firm characteristics } \\
\hline Market Cap & & $\begin{array}{c}-0.007 * * * \\
(-5.805)\end{array}$ & $\begin{array}{c}-0.005 * * * \\
(-2.940)\end{array}$ & $\begin{array}{c}-0.005 * * * \\
(-2.957)\end{array}$ \\
\hline Age & & $\begin{array}{c}-0.000 \\
(-0.356)\end{array}$ & $\begin{array}{c}-0.000 \\
(-1.533)\end{array}$ & $\begin{array}{c}-0.000 \\
(-1.096)\end{array}$ \\
\hline Loss & & $\begin{array}{c}0.006 \\
(1.498)\end{array}$ & $\begin{array}{c}0.005 \\
(0.907)\end{array}$ & $\begin{array}{c}0.005 \\
(0.903)\end{array}$ \\
\hline ReverseZ & & $\begin{array}{c}0.002^{* * *} \\
(2.738)\end{array}$ & $\begin{array}{c}0.002 \\
(1.551)\end{array}$ & $\begin{array}{l}0.002^{*} \\
(1.682)\end{array}$ \\
\hline Foreign Currency Trans & & $\begin{array}{c}0.012^{* * *} \\
(3.300)\end{array}$ & $\begin{array}{c}0.003 \\
(0.759)\end{array}$ & $\begin{array}{c}0.004 \\
(0.908)\end{array}$ \\
\hline Restructure & & $\begin{array}{c}0.007^{* *} \\
(2.429)\end{array}$ & $\begin{array}{c}0.005 \\
(1.231)\end{array}$ & $\begin{array}{c}0.004 \\
(0.962)\end{array}$ \\
\hline Growth & & $\begin{array}{c}-0.004 \\
(-0.937)\end{array}$ & $\begin{array}{c}-0.002 \\
(-0.605)\end{array}$ & $\begin{array}{c}-0.002 \\
(-0.324)\end{array}$ \\
\hline Prior Restatement & & $\begin{array}{c}0.027 * * * \\
(3.849)\end{array}$ & $\begin{array}{c}-0.037 * * * \\
(-9.807)\end{array}$ & $\begin{array}{c}-0.037 * * * \\
(-10.359)\end{array}$ \\
\hline Governance & & & & \\
\hline Percent Outsiders & & $\begin{array}{c}0.004 \\
(0.426)\end{array}$ & $\begin{array}{c}-0.021 \\
(-1.335)\end{array}$ & $\begin{array}{c}-0.019 \\
(-1.271)\end{array}$ \\
\hline Board Size & & $\begin{array}{c}0.007 \\
(0.901)\end{array}$ & $\begin{array}{c}-0.011 \\
(-0.977)\end{array}$ & $\begin{array}{c}-0.017 \\
(-1.392)\end{array}$ \\
\hline AC Size & & $\begin{array}{c}-0.002 \\
(-0.186)\end{array}$ & $\begin{array}{c}-0.010 \\
(-0.720)\end{array}$ & $\begin{array}{c}-0.002 \\
(-0.165)\end{array}$ \\
\hline AC Directorships & & $\begin{array}{c}-0.001 \\
(-0.138)\end{array}$ & $\begin{array}{c}0.008 \\
(0.733)\end{array}$ & $\begin{array}{c}0.003 \\
(0.267)\end{array}$ \\
\hline Auditor Change & & $\begin{array}{c}0.017^{* *} \\
(1.964)\end{array}$ & $\begin{array}{c}0.021^{* * *} \\
(4.432)\end{array}$ & $\begin{array}{c}0.021^{* * * *} \\
(4.341)\end{array}$ \\
\hline Big4 & & $\begin{array}{c}0.001 \\
(0.325)\end{array}$ & $\begin{array}{c}0.015 \\
(1.385)\end{array}$ & $\begin{array}{c}0.016 \\
(1.414)\end{array}$ \\
\hline Other links & & & & \\
\hline Post-Disclosure Link - Auditor & & $\begin{array}{c}0.000 \\
(0.131)\end{array}$ & $\begin{array}{c}-0.003 \\
(-0.682)\end{array}$ & $\begin{array}{c}-0.001 \\
(-0.324)\end{array}$ \\
\hline Post-Disclosure Link - Industry & & $\begin{array}{c}0.000 \\
(0.000)\end{array}$ & $\begin{array}{c}-0.003 \\
(-0.746)\end{array}$ & $\begin{array}{c}-0.003 \\
(-0.845)\end{array}$ \\
\hline Total Interlocks & & $\begin{array}{c}-0.003 \\
(-1.056)\end{array}$ & $\begin{array}{c}-0.004 \\
(-0.908)\end{array}$ & $\begin{array}{c}-0.004 \\
(-0.922)\end{array}$ \\
\hline Industry and Year FE & & Yes & Yes & Yes \\
\hline $\begin{array}{l}\text { Observations } \\
\text { Pseudo } R^{2}\end{array}$ & & $\begin{array}{l}9,129 \\
0.185\end{array}$ & $\begin{array}{l}9,129 \\
0.130\end{array}$ & $\begin{array}{l}9,129 \\
0.149 \\
\end{array}$ \\
\hline
\end{tabular}


This table presents a logit regression for models (1) - (3). The dependent variable in column 1 is ICMW, which is coded one if the firm reports a material weakness under SOX 404 and zero otherwise. In columns 2 and 3, the dependent variable is Misstate, coded one if the firm's current year reports are later restated and coded zero otherwise. The independent variable in columns 1 and 3 is $P D I$, which is coded one if a firm in year $j$ has an audit committee member who concurrently serves on the board of a disclosing firm in a year that is during the disclosing firm's post-disclosure period; coded zero otherwise. The post-disclosure period is defined as the three-year period following the disclosing firm's material weakness (ICMW) disclosure. The independent variable in column 2 is PDI-Restate, which is coded one if a firm in year $j$ has an audit committee member who concurrently serves on the board of a firm that disclosed a restatement of its financial statements in a year that is during its three-year postdisclosure period. All other variables are defined in the Appendix. The table presents the marginal effects and zstatistics (in parentheses) of each variable. Industry and year fixed effects are included. Standard errors are clustered by firm. *, **, and *** represent significance at the 10 percent, 5 percent, and 1 percent levels using a two-tailed test. 
Table 3: Alternate PDI variables and ICMW disclosures

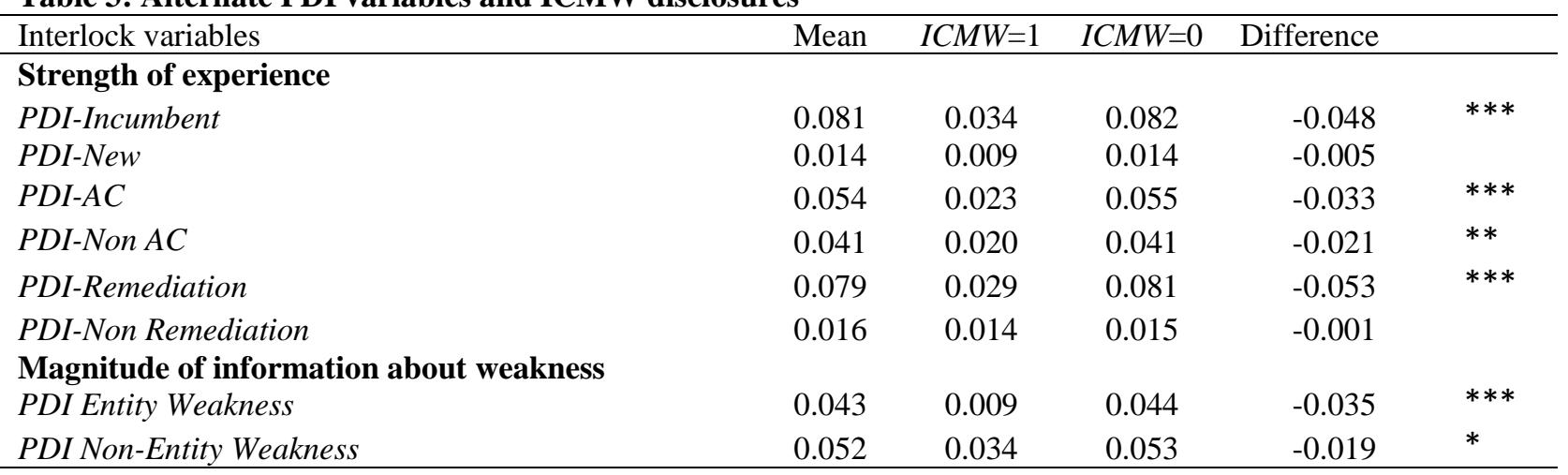

This table provides the mean of each alternate version of PDI used in the cross-sectional analysis and also compares the mean of each $P D I$ variable for observations with a material weakness $(I C M W=1)$ and without a material weakness $(I C M W=0)$. The variables are defined in the Appendix. *, **, and *** represent significance at the 10 percent, 5 percent, and 1 percent levels using a two-tailed test. 
Table 4: Cross-sectional analysis

\begin{tabular}{|c|c|c|c|c|c|}
\hline Variable & Prediction & $\begin{array}{c}(1) \\
I C M W\end{array}$ & $\begin{array}{c}(2) \\
I C M W\end{array}$ & $\begin{array}{c}(3) \\
I C M W\end{array}$ & $\begin{array}{c}(4) \\
I C M W\end{array}$ \\
\hline PDI-Incumbent & - & $\begin{array}{c}\mathbf{- 0 . 0 1 5} * * * \\
(-3.249)\end{array}$ & & & \\
\hline PDI-New & ? & $\begin{array}{c}0.009 \\
(0.320)\end{array}$ & & & \\
\hline PDI-AC & - & & $\begin{array}{c}-\mathbf{0 . 0 0 9} * * \\
(-2.481)\end{array}$ & & \\
\hline PDI-Non AC & $?$ & & $\begin{array}{c}-0.008 \\
(-1.262)\end{array}$ & & \\
\hline PDI-Remediation & - & & & $\begin{array}{c}-\mathbf{0 . 0 1 0} * * \\
(-2.502)\end{array}$ & \\
\hline PDI-Non Remediation & ? & & & $\begin{array}{c}-0.004 \\
(-0.537)\end{array}$ & \\
\hline PDI Entity Weakness & - & & & & $\begin{array}{c}-\mathbf{0 . 0 1 5} * * * \\
(-4.711)\end{array}$ \\
\hline PDI Non-Entity Weakness & ? & & & & $\begin{array}{c}-0.004 \\
(-0.723)\end{array}$ \\
\hline Controls Included & & Yes & Yes & Yes & Yes \\
\hline Industry and Year FE & & Yes & Yes & Yes & Yes \\
\hline Observations & & 9,129 & 9,129 & 9,129 & 9,129 \\
\hline Pseudo $R^{2}$ & & 0.186 & 0.185 & 0.185 & 0.186 \\
\hline
\end{tabular}

This table presents a logit regression for model (1) but modifies the PDI variable. PDI-Incumbent (New) is coded one if a firm in year $j$ has an audit committee member who (i) concurrently serves on the board of a disclosing firm in a year that is during the disclosing firm's post-disclosure period and (ii) joined the disclosing firm's board before (after) the ICMW disclosure; coded zero otherwise. PDI-AC is coded one if a firm in year $j$ has an audit committee member who concurrently serves on the audit committee of the board of a disclosing firm in a year that is during the disclosing firm's post-disclosure period; coded zero otherwise. PDI-Non AC is coded one if a sample firm in year $j$ has an audit committee member who concurrently serves on the board (but not on the audit committee) of a disclosing firm in a year that is during the disclosing firm's post-disclosure period; coded zero otherwise. PDI (Non) Remediation is coded one if a firm in year $j$ has an audit committee member who (i) concurrently serves on the board of a disclosing firm in a year that is during the disclosing firm's post-disclosure period and (ii) the disclosing firm remediated (did not remediate) its weakness; coded zero otherwise. PDI-(Non) Entity Weakness is coded one if a firm in year $j$ has an audit committee member who (i) concurrently serves on the board of a disclosing firm in a year that is during the disclosing firm's post-disclosure period and (ii) the disclosing firm's material weakness is (not) classified an entity-wide weakness; coded zero otherwise. The dependent variable is ICMW, which is coded one if the firm reports a material weakness under SOX 404 and zero otherwise. Control variables from model (1) are included but omitted for brevity. The table presents the marginal effects and $z$-statistics (in parentheses) of each variable. Industry and year fixed effects are included. Standard errors are clustered by firm. ${ }^{* *}$ and ${ }^{* * *}$ represent significance at the 5 percent and 1 percent levels using a two-tailed test. 
Table 5: Controlling for director quality

$(2)$

(1)

\begin{tabular}{lccc} 
Variable & Prediction & ICMW & Turnover ICMW \\
\hline PDI & - & $\mathbf{- 0 . 0 0 9 * *}$ & $\mathbf{- 0 . 0 0 8 * *}$ \\
& & $(-2.146)$ & $(-2.224)$ \\
High Quality Director & $?$ & 0.003 & \\
& & $(0.873)$ & Yes \\
Controls Included & & Yes & Yes \\
Industry and Year FE & & 9,129 & 2,761 \\
Observations & & 0.185 & 0.234 \\
Pseudo $R^{2}$ & & & \\
\hline
\end{tabular}

This table presents a logit regression for model (1). The dependent variable in column 1 is ICMW, which is coded one if the firm reports a material weakness under SOX 404 and zero otherwise. The independent variable in column 1 is $P D I$, which is coded one if a firm in year $j$ has an audit committee member who concurrently serves on the board of a disclosing firm in a year that is during the disclosing firm's post-disclosure period; coded zero otherwise. High Quality Director is coded one if a firm has an audit committee member whose total board seats is above the sample median of board seats for all directors in the sample; coded zero otherwise. Column 2 runs model (1) only on the subsample of observations without any board turnover between the prior and current year. Control variables from model (1) are included but omitted for brevity. The table presents the marginal effects and $z$-statistics (in parentheses) of each variable. Industry and year fixed effects are included. Standard errors are clustered by firm. ** represents significance at the 5 percent level using a two-tailed test. 
Table 6: Director selection analysis

Panel A: Controlling for director selection

\begin{tabular}{lcc} 
Variable & Prediction & ICMW \\
\hline PDI-Alternative & - & $\mathbf{- 0 . 0 0 6 * *}$ \\
& $(-2.396)$ \\
Controls Included & Yes \\
Industry and Year FE & Yes \\
Observations & 9,129 \\
Pseudo $R^{2}$ & 0.184 \\
\hline
\end{tabular}

Panel B: AC Director Selection Model

\begin{tabular}{lc} 
Variable & New Dir \\
\hline Post Disclosure & $-\mathbf{0 . 0 1 8 ^ { * * * }}$ \\
Similar Size & $(-6.067)$ \\
& 0.004 \\
Same Industry & $(1.033)$ \\
& 0.000 \\
Same Region & $(0.346)$ \\
Age & $0.007^{*}$ \\
& $(1.951)$ \\
Avg Perf & $-0.002^{* * *}$ \\
& $(-18.214)$ \\
Directorships & $0.007^{*}$ \\
Year FE & $(1.844)$ \\
& $0.015^{* * *}$ \\
Observations & $(7.864)$ \\
Pseudo $R^{2}$ & Yes \\
\hline
\end{tabular}

Panel A presents model (1) but modifies PDI. PDI-Alternative is coded one if a firm in year $j$ has an audit committee member who (i) concurrently serves on the board of a disclosing firm in a year that is during the disclosing firm's post-disclosure period and (ii) was on the connected firm's board before the time of ICMW disclosure by the disclosing firm; coded zero otherwise. The dependent variable is ICMW, which is coded one if the firm reports a material weakness under SOX 404 and zero otherwise. Control variables from model (1) are included but omitted for brevity. Panel B presents a selection model for newly appointed directors with audit committee experience. The dependent variable, New Dir, is coded one if the director received a new appointment in a given year and zero otherwise. Post Disclosure is coded one if the director experienced an ICMW disclosure in the past three years at any of his/her firms. Similar Size is coded one if the director sits on the board of a firm in the same size deciles as the prospective new firm. Same Industry and Same Region are coded one if the director sits on a board of a firm in the same industry or region as the prospective new firm, respectively. Age is the director's age, Avg Perf is the average stock return of all of the director's firms, and Directorships is the number of board seats held by the director. Year fixed effects are included and standard errors are clustered at the director level. The table presents the marginal effects and $z$-statistics (in parentheses) of each variable. ${ }^{*}, * *$, and $* * *$ represent significance at the 10 percent, 5 percent, and 1 percent levels using a two-tailed test. 
Table 7: Sensitivity analysis

\begin{tabular}{|c|c|c|c|c|c|}
\hline Variable & $\begin{array}{c}(1) \\
\text { Observation dropped after } \\
\text { ICMW reported }\end{array}$ & $\begin{array}{c}(2) \\
\text { Discrete-time logit } \\
\text { model }\end{array}$ & $\begin{array}{c}\text { (3) } \\
\text { 2004-2007 } \\
\text { observations }\end{array}$ & $\begin{array}{c}\text { (4) } \\
\text { 2008-2012 } \\
\text { observations } \\
\end{array}$ & $\begin{array}{c}(5) \\
\text { Alternative interlock } \\
\text { measurement }\end{array}$ \\
\hline$P D I$ & $\begin{array}{c}\mathbf{- 0 . 0 0 8 * *} \\
(-2.955)\end{array}$ & $\begin{array}{c}-\mathbf{0 . 0 0 8 * *} \\
(-2.850)\end{array}$ & $\begin{array}{l}\mathbf{- 0 . 0 1 9 *} \\
(-1.889)\end{array}$ & $\begin{array}{c}-\mathbf{0 . 0 0 7} * * * \\
(-3.725)\end{array}$ & $\begin{array}{c}\mathbf{- 0 . 0 1 2 * *} \\
(-2.209)\end{array}$ \\
\hline $\begin{array}{l}\text { Controls Included } \\
\text { Industry and Year FE }\end{array}$ & $\begin{array}{l}\text { Yes } \\
\text { Yes }\end{array}$ & $\begin{array}{l}\text { Yes } \\
\text { Yes }\end{array}$ & $\begin{array}{l}\text { Yes } \\
\text { Yes }\end{array}$ & $\begin{array}{l}\text { Yes } \\
\text { Yes }\end{array}$ & $\begin{array}{l}\text { Yes } \\
\text { Yes }\end{array}$ \\
\hline $\begin{array}{l}\text { Observations } \\
\text { Pseudo } R^{2}\end{array}$ & $\begin{array}{l}8,425 \\
0.178\end{array}$ & $\begin{array}{c}8,425 \\
\text { N/A }\end{array}$ & $\begin{array}{l}3,576 \\
0.117\end{array}$ & $\begin{array}{l}5,553 \\
0.186\end{array}$ & $\begin{array}{l}7,894 \\
0.192\end{array}$ \\
\hline
\end{tabular}

This table presents alternate specifications for model (1). ICMW, or a modified version of ICMW, is the dependent variable in all columns. Column 1 presents model (1) but modifies the dependent variable by dropping observations from the sample after they report a material weakness. Column 2, which uses the same modified dependent variable as in column 1, presents a discrete-time logistic model. Column 3 presents the results of model (1) for the years 2004-2007, while column 4 presents the model for the years 2008-2012. In column 5, the independent variable is the number of post-disclosure interlocks (PDI) scaled by total interlocks. The analysis of column 5 excludes observations that do not have any interlocks. PDI is coded one if a firm in year $j$ has an audit committee member who concurrently serves on the board of a disclosing firm in a year that is during the disclosing firm's post-disclosure period; coded zero otherwise. The postdisclosure period is defined as the three-year period following the disclosing firm's material weakness disclosure. Control variables from model (1) are included but omitted for brevity. The table presents the marginal effects and z-statistics (in parentheses) of each variable. Industry and year fixed effects are included. Standard errors are clustered by firm. *, **, and *** represent significance at the 10 percent, 5 percent, and 1 percent levels using a two-tailed test.

This article is protected by copyright. All rights reserved. 
Table 8: Analysis of pre-disclosure period

\begin{tabular}{lcc} 
Variable & Prediction & ICMW \\
\hline Pre-Disclosure Interlock & + & $\mathbf{0 . 1 2 0} * * *$ \\
& $(6.558)$ \\
Controls Included & Yes \\
Industry and Year FE & Yes \\
& \\
Observations & 9,129 \\
Pseudo $R^{2}$ & 0.282 \\
\hline
\end{tabular}

This table presents model (1) but alters the independent variable. The dependent variable is ICMW, which is coded one if the firm reports a material weakness under SOX 404 and zero otherwise. Pre-Disclosure Interlock is coded one if the firm has an audit committee member who concurrently serves on a disclosing firm in a year that is during that firm's pre-disclosure period, which is defined as the three-year period leading up to the disclosing firm's ICMW disclosure. Control variables from model (1) are included but omitted for brevity. The table presents the marginal effects and z-statistics (in parentheses) of each variable. Industry and year fixed effects are included. Standard errors are clustered by firm. ${ }^{* * *}$ represents significance at the 1 percent level using a two-tailed test. 